\title{
Typhoon-dominated Influence on Wood Debris Distribution and Transportation in a High Gradient Headwater Catchment
}

\author{
CHEN Su-Chin, CHAO Yi-Chiung*, CHAN Hsun-Chuan \\ Department of Soil and Water Conservation, National Chung Hsing University, No. 25o, Kuo-Kuang Rd., 40227 Taichung, \\ Chinese Taipei \\ ${ }^{*}$ Corresponding author,e-mail: d9542007@mail.nchu.edu.tw
}

(C) Science Press and Institute of Mountain Hazards and Environment, CAS and Springer-Verlag Berlin Heidelberg 2013

\begin{abstract}
Wood debris is an important component of mountain streams. It causes serious damage and renders difficulty of water resource management in Taiwan. In this study, the quantity of wood debris and variation of migratory wood debris during flood events were examined. The downstream of Gaoshan Creek and Qijiawan Creek, located at Central Taiwan, was selected as the study area. The distribution and dynamic of wood debris in a high gradient headwater catchment were quantified using field surveys. A formula of critical depth for wood debris entrainment was used to evaluate the wood debris migration during three flooding events. In the study area, wood abundance and unit volume increased downstream, and wood density decreased downstream within a channel network. The channel morphology, riparian vegetation, and wood debris characteristics were found to influence the wood storage. As a result, the wood debris has an irregular accumulative distribution in the steep stream, and it migrates easily in the stream because of a high flow discharge. Strong relationships between the channel width and wood debris variables are discovered. Moreover, wood debris has a tendency to accumulate at sites with low stream power and wood debris dams, topographical notches, and unique geological structures. Our findings assist in the understanding of the effects of channel characteristics on distributions of wood debris in steep stream systems.
\end{abstract}

Keywords: Wood debris; Spatial distribution

Received: 30 March 2013

Accepted: 24 May 2013 characteristics; Wood debris migration; Flood events

\section{Introduction}

The woody materials falling into stream banks or channels from sources such as dead trees are referred to as wood debris. This debris is common throughout forested stream systems. Recent studies have highlighted the ecological and geomorphological importance of wood debris to forested stream ecosystems. Wood debris can create and alter channel hydraulics, channel morphology, sediment transport, organic matter storage, aquatic habitat complexity, and biological communities (Bilby 1981; Chen et al. 2006; Gurnell et al. 2002; Keller and Swanson 1979; Manners and Doyle 2008; Montgomery et al. 1995). Transportation and storage of wood debris are evidently influenced by a bank's characteristics (Latterell and Naiman 2007). In small streams, wood debris produced by forest dynamics and hillslope processes are retained, remaining on the valley floor (Harmon et al. 1986; Nakamura and Swanson 1993; Seo et al. 2010), and may be transported during regular floods (Harmon et al. 1986; Seo et al. 2010). In medium and large streams, wood debris is primarily generated by bank undercutting in the adjacent riparian zone (Martin and Benda 2001; Seo et al. 2010). In areas with sufficient stream power, wood debris has a 
higher potential to mobilize with increasing discharge as the stream size and depth increase (Baillie et al. 2008; Bilby and Ward 1989; Chen et al. 2006; Seo et al. 2010).

Tropical cyclones, such as typhoons, occur frequently in tropical regions and trigger numerous landslides, introducing large amounts of wood debris into streams and rivers (Wohl et al. 2009; Wohl and Ogden 2013). However, the presence of wood debris may be regarded as undesirable from a flood protection perspective because it markedly increases the probabilities of hydraulic structure damages or waterway blocks. For instance, Shihmen Reservoir, located in the northwestern portion of Taiwan, was unable to function effectively because a large amount of wood debris was trapped in the reservoir following Typhoons Aere and Haima in 2004. The total volume of salvaged wood in the reservoir impoundment zone was 54,000 $\mathrm{m}^{3}$ ( $\mathrm{Lu}$ and Hwang 2006). Moreover, the floods following Typhoon Morakot in 2009 contributed to a total 3.8-8.4 $\mathrm{Tg}$ of wood debris spread along the coast and transported to the ocean around Taiwan (West et al. 2011). The wood debris not only damaged roads and bridges, but also severely affected human life, fisheries, and agriculture. Figure 1 shows the wood debris disasters in Eastern Taiwan following Typhoon Morakot. The wood debris accumulated behind the bridge and filled the harbor.

A literature review indicates that ecological programs have attempted to enhance our understanding of how wood debris contributes to habitat quality, aesthetics, and water quality. Moreover, wood debris introduces significant burdens on flood protection, and especially endangers the safety of hydraulic structures. Examining the distribution of wood debris before and after flood events in a headwater catchment is the main concern when reducing the risks of damage toward flood control structures. Literature discussing the carbon export in Taiwan after Typhoon Morakot is scant (Hilton et al. 2008; West et al. 2011). There are currently no specific studies that have indicated the wood storage characteristics and entrainment in Taiwan. Therefore, tis study extensively explores the quantities of wood debris stored in a steep mountain stream and threshold of flood to trigger the transport of wood debris downstream. A forested mountain stream was selected as the study area. The aims of this study are as follows: (a) Quantify the characteristics of wood debris (spatial distribution and accumulative distribution); and (b) demonstrate the transportation of wood debris (mobility and relationship with unit stream power) in steep mountain streams.

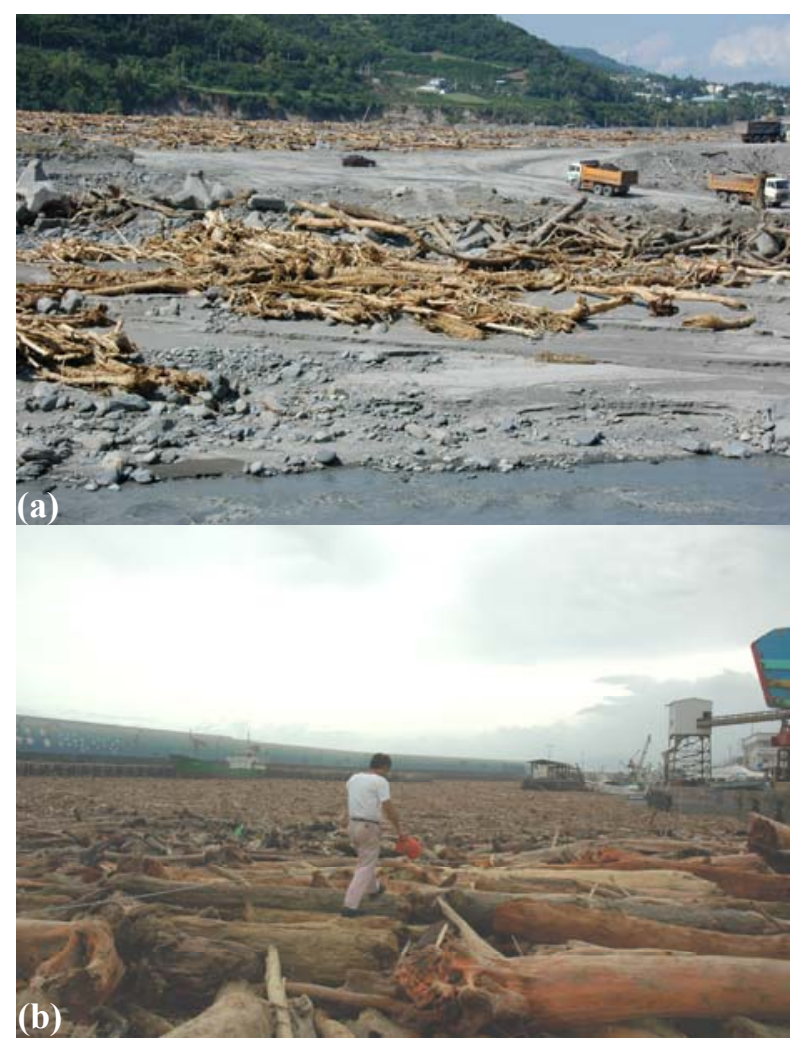

Figure 1 The wood debris disaster in Eastern Taiwan following Typhoon Morakot: (a) amount of wood debris spread across and accumulated on the Taimali river; (b) the wood debris filled the harbor during Typhoon Morakot. The engineering trucks and the man provide scale in the figure.

\section{Study Area and Methods}

\subsection{Study area}

The study area is downstream of Gaoshan Creek and Qijiawan Creek. It is located at the Qijiawan catchment in Shei-Pa National Park in Central Taiwan (Figure 2). The catchment area and the length of the study area within Gaoshan Creek are $21 \mathrm{~km}^{2}$ and $1.8 \mathrm{~km}$, respectively. The channel widths range from 3 to $45 \mathrm{~m}$ with a mean channel 


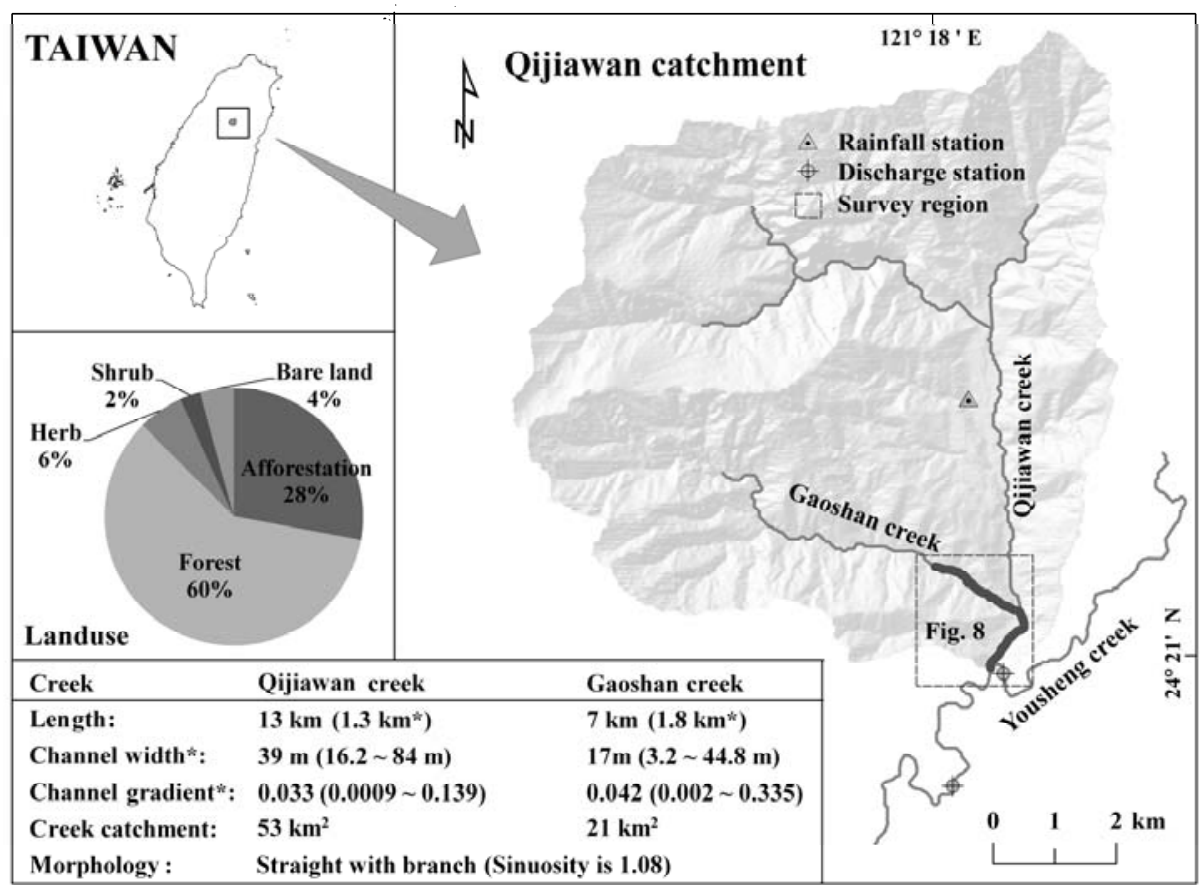

Figure 2 Location map of the study reach showing basic catchment and morphological characteristics. The symbols on the map show information concerning the survey region.
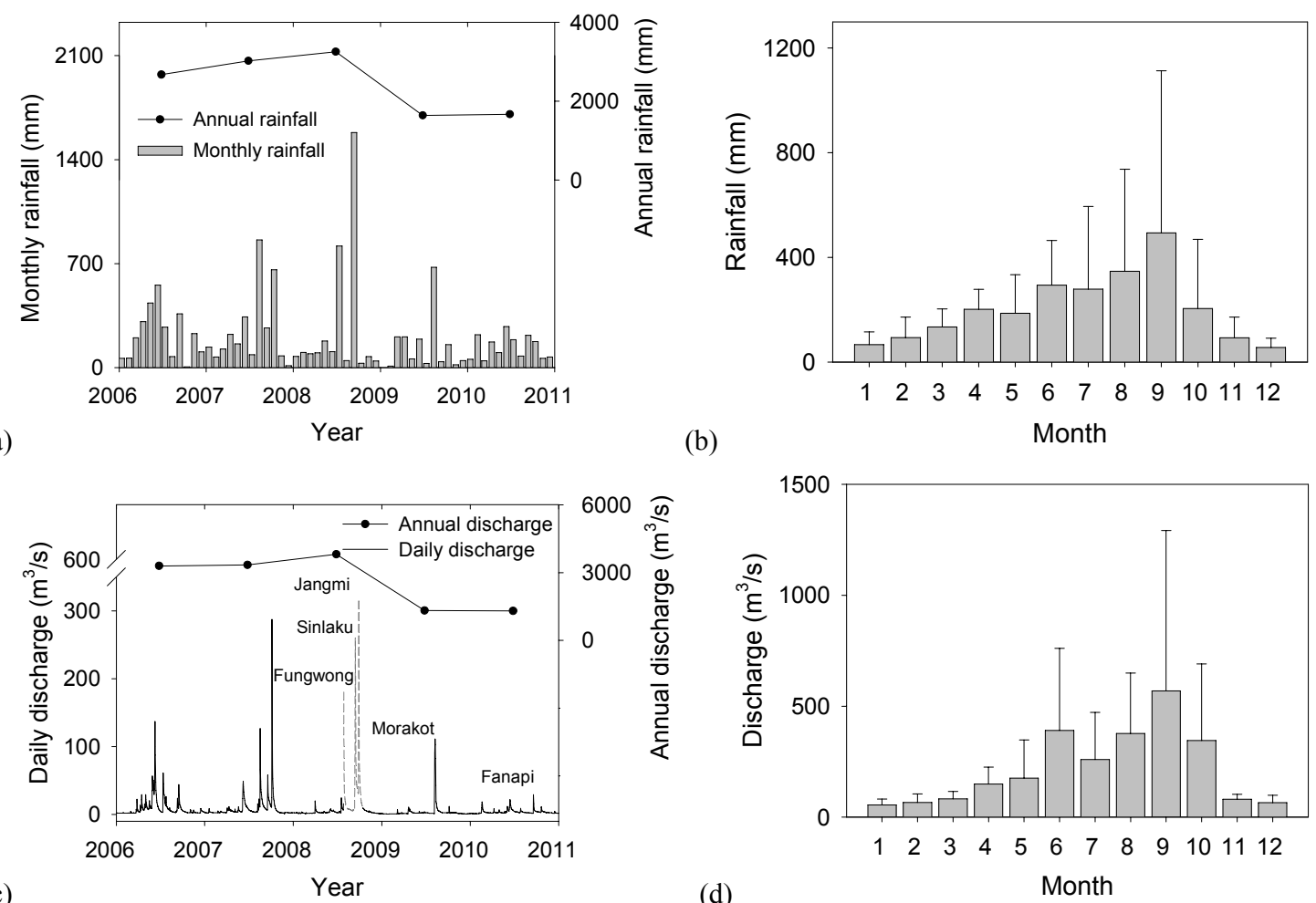

Figure 3 The hydrological records in the Qijiawan catchment. (a) shows the annual and monthly rainfall, and the annual mean precipitation at the Taoshan rainfall station (2006 to 2010) was 2,451 mm; a high daily precipitation event was $495 \mathrm{~mm}$ (typhoon Jangmi); (b) shows the mean monthly rainfall variability and its error bar; (c) Flow discharge was measured at the Qijiawan creek water stage, and the mean daily flow discharge was $5.8 \mathrm{~m}^{3} / \mathrm{s}(2006$ to 2010). High flow events in typhoons Jangmi was $317 \mathrm{~m} 3 / \mathrm{s}$ (2008-09-28); (d) shows the mean monthly discharge variability and its error bar; The Yousheng creek water stage missed the flow discharge from July 27 to October 19 , 2008; therefore, the short-dash-line only performed the discharge measured at the Qijiawan creek water stage. 
width of $17 \mathrm{~m}$. The altitudes within the Gaoshan creek catchment range between 1,730 $\mathrm{m}$ and 3,790 $\mathrm{m}$ with a mean altitude of $2,577 \mathrm{~m}$. The channel gradients range between $0.002 \mathrm{~m} / \mathrm{m}$ and 0.335 $\mathrm{m} / \mathrm{m}$. The catchment area and the length of the study area within Qijiawan Creek are $53 \mathrm{~km}^{2}$ and1.3 km, respectively. The channel widths range from 16 to $84 \mathrm{~m}$ with a mean channel width of 39 $\mathrm{m}$. The altitudes within Qijiawan Creek range between $1,690 \mathrm{~m}$ and $3,880 \mathrm{~m}$ with a mean altitude of $2,133 \mathrm{~m}$. The channel gradient ranges between $0.0009 \mathrm{~m} / \mathrm{m}$ and $0.139 \mathrm{~m} / \mathrm{m}$.

The dominant land cover within the study area consisted of native forest (60\%) and forest plantations (28\%). Other minor land cover included herbaceous vegetation (6\%), bare land (4\%), and shrubs (2\%). The native forest is primarily conifer trees, such as Tsuga chinensis var. formosana (storage volume, $599 \mathrm{~m}^{3} / \mathrm{ha}$ ) and Abies kawakamii (storage volume, $391 \mathrm{~m}^{3} / \mathrm{ha}$ ) and conifer mixed broadleaf (storage volume, 285 $\mathrm{m} 3 / \mathrm{ha}$ ). The plantations are primarily artificial conifer (storage volume, $156 \mathrm{~m}^{3} / \mathrm{ha}$ ) (Figure 2). The local geological strata consisted of Alluvium, Paileng Formation Meitzulin Member (thickbedded quartz sandstone intercalated argillite), Shuichangliu Formation (argillite and slate), and Chiayang Formation (slate with thin-bedded siltstone). The stratigraphic age ranged from Holocene to Eocene (Chang et al. 1997).

The locations of the Taoshan rainfall station $\left(24^{\circ} 23^{\prime} 21^{\prime \prime N}, 1^{12} 1^{\circ} 17^{\prime} 47^{\prime \prime} \mathrm{E}\right)$ and Qijiawan creek discharge station $\left(24^{\circ} 19^{\prime} 56^{\prime \prime} \mathrm{N}, 121^{\circ} 17^{\prime} 38^{\prime \prime} \mathrm{E}\right)$ are also indicated in Figure 2. Figure 3 shows the hydrological records of rainfall and discharge from January 2006 to December 2010. The annual rainfall in the study area is highly variable. It ranges from 1,640 and $3,252 \mathrm{~mm}$ (from 2006 to 2010), with a mean annual rainfall of $2,451 \mathrm{~mm}$ (Figure 3(a)). Figure 3 (b) shows the mean monthly rainfall and its error bar; $61 \%$ of rainfall occurs from June to October. The variability of error bar was influence by the typhoons from July to October; particularly in September. Typhoons Sinlaku and Jangmi carried heavy rainfall to the study region in September 2008. The peak flow discharge and mean annual discharge were $317 \mathrm{~m}^{3} / \mathrm{s}$ and $86 \mathrm{~m}^{3} / \mathrm{s}$, respectively. The dominant severe weather events in the Qijiawan catchment during the last 5 years were Typhoon Fung-wong in July 2008 (total rainfall of $559 \mathrm{~mm}$ ), Typhoons Sinlaku and Jangmi in September 2008 (total rainfall of $877 \mathrm{~mm}$ and $648 \mathrm{~mm}$, respectively), and Typhoon Morakot in August 2009 (total rainfall of $659 \mathrm{~mm}$ ), as shown in Figure 3(c). Discharge occurred primarily from June to October (73\%). This indicates that, in the study area, June to October is the wet season and November to May is the dry season (Figure 3 (d)). The hydrological characteristics are highly variable in the Qijiawan catchment. The mean annual rainfall from 2006 to 2008 was $2,983 \mathrm{~mm}$, but decreased to approximately $1,330 \mathrm{~mm}$ from 2009 to 2010. A diversity of wood debris is expected in the study area because of the progression of these variable rainfall events.

\subsection{Field surveys}

In this study, wood debris was defined as wood pieces of at least $10 \mathrm{~cm}$ in diameter and $1 \mathrm{~m}$ in length (Andrus et al. 1988; Gippel 1995; Keller and Swanson 1979). Field surveys were performed to identify the wood debris in the study area, and the wood debris dimensions were recorded. The wood debris was classified according to the location and orientation during the surveys. The orientations between the wood debris and flow direction were recorded as follows: (a) parallel to the flow direction, (b) perpendicular to the flow direction, and (c) oblique to the flow direction. The locations were classified as follows: (a) adjacent to the floodplain, (b) bank edge, (c) across the channel, (d) partly across the channel, and (e) channel flow. All wood debris was measured for small-end diameter, large-end diameter, and length by using a tape measure. The two diameters were averaged to calculate mean diameter for individual wood debris. The volume of individual wood debris was calculated using Frustrum's formula (Harmon and Sexton 1996), assuming that the debris possessed a cylindrical shape.

$$
V_{w}=l_{w}\left(A_{b}+A_{t}\right) / 2
$$

Where $V_{w}$ is individual wood piece volume $\left(\mathrm{m}^{3}\right) ; l_{w}$ is wood debris length (m); $A_{b}$ is the area at the base of the wood debris $\left(\mathrm{m}^{2}\right)$; and $A_{t}$ is the area at the top of the wood debris $\left(\mathrm{m}^{2}\right)$. The volumes of wood debris jams were used as the sum of the volume of individual wood pieces. If individual wood pieces in the wood debris jams were highly entangled and 
difficult to measure, the width, height, and length were summed to give an approximate volume.

The first survey in the study area was conducted in January 2009. The wood debris within the bankfull channel and in the adjacent active floodplain was tagged. The characteristics of the wood debris were recorded. A second survey was performed following Typhoon Morakot in September 2009, and the tagged wood debris within the study reach was recorded. New wood debris was tagged, and data concerning the wood debris were recorded. The third survey was conducted in September 2010. Tagged wood debris was recorded, and new wood debris was tagged and measured. The characteristics of wood debris that moved between each survey were identified through comparisons between the results of each survey.

\subsection{Data analysis}

Two categories of factors were considered for analysis in this study. The wood debris characteristics category comprises wood length $\left(l_{w}\right)$, wood diameter $\left(d_{w}\right)$, abundance (pieces/10om), density (pieces/ha), piece volume $\left(\mathrm{m}^{3}\right)$, unit volume ( $\left.\mathrm{m}^{3} / 100 \mathrm{~m}\right)$, and volume/unit area $\left(\mathrm{m}^{3} / \mathrm{ha}\right)$. The channel characteristics category comprises channel length $(L)$, surveyed channel length $\left(L_{s}\right)$, channel width $(W)$, mean channel gradient $(S)$, and creek catchment $\left(A_{c}\right)$. The values of $l_{w}$ and $d_{w}$ were collected from the field survey data. The channel lengths and widths were measured using rangefinder in the field, and the values of $L$, and $S$ were extracted from a digital elevation model (DEM, $5 \mathrm{~m} \times 5 \mathrm{~m}$ spatial resolution). All analyses were performed using ANOVA within the SPSS software (version 12.0). This study uses linear regression to examine the relationship between the dependent variables (wood characteristics) and independent variables (channel characteristics). Pearson's correlation coefficient $(r)$ was used to determine the relationship strength between the wood and channel characteristics. Regression results with $p$ - values $<0.05$ were considered significant.

\section{Results}

\subsection{Characteristics of wood debris}

The retrieved data indicate that 552,618 , and 1071 wood debris were tagged in January 2009, September 2009, and September 2010, respectively (Table 1 ). The abundance (ranging from 19 to 38 pieces/100 $\mathrm{m}$ ), density (ranging from 90 to 175 pieces/ha), unit volume (ranging from 20 to $23 \mathrm{~m}^{3} / 100 \mathrm{~m}$ ), and volume/unit (ranging from 95 to $105 \mathrm{~m} 3 / \mathrm{ha}$ ) increased during the survey periods, but the wood debris dimensions (length, mean wood debris size, and diameter) decreased.

Table 1 Characteristics of the woody pieces

\begin{tabular}{|c|c|c|c|c|c|c|c|c|c|}
\hline & \multicolumn{3}{|c|}{ 2009-01 } & \multicolumn{3}{|c|}{ 2009-09 } & \multicolumn{3}{|c|}{ 2010-09 } \\
\hline & $\begin{array}{l}\text { Gaoshan } \\
\text { creek }\end{array}$ & $\begin{array}{l}\text { Qijiawan } \\
\text { creek }\end{array}$ & Total & $\begin{array}{l}\text { Gaoshan } \\
\text { creek }\end{array}$ & $\begin{array}{l}\text { Qijiawan } \\
\text { creek }\end{array}$ & Total & $\begin{array}{l}\text { Gaoshan } \\
\text { creek }\end{array}$ & $\begin{array}{l}\text { Qijiawan } \\
\text { creek }\end{array}$ & Total \\
\hline Total wood pieces & 261 & 291 & 552 & 353 & 265 & 618 & 583 & 488 & 1071 \\
\hline Abundance (pieces/10om) & 14.61 & 27.25 & 19.34 & 19.81 & 24.81 & 21.68 & 32.85 & $45 \cdot 98$ & 37.76 \\
\hline Density (pieces/ha) & 99.92 & 82.41 & 89.86 & $135 \cdot 53$ & 75.05 & 100.76 & 224.73 & 139.05 & 175.48 \\
\hline Mean length*(m) & $\begin{array}{l}5 \cdot 54 \\
\pm 3.90\end{array}$ & $\begin{array}{l}4.66 \\
\pm 3.12\end{array}$ & $\begin{array}{l}5.09 \\
\pm 3.55\end{array}$ & $\begin{array}{l}4.89 \\
\pm 4.01\end{array}$ & $\begin{array}{l}4.16 \\
\pm 2.79\end{array}$ & $\begin{array}{l}4.59 \\
\pm 3.55\end{array}$ & $\begin{array}{l}3.55 \\
\pm 2.88\end{array}$ & $\begin{array}{l}4.19 \\
\pm 3.10\end{array}$ & $\begin{array}{l}3.84 \\
\pm 3.00\end{array}$ \\
\hline Mean diameter* $(\mathrm{cm})$ & $\begin{array}{l}36.68 \\
\pm 27.37\end{array}$ & $\begin{array}{l}29.58 \\
\pm 21.91\end{array}$ & $\begin{array}{l}33.04 \\
\pm 24.96\end{array}$ & $\begin{array}{l}31.87 \\
\pm 22.63\end{array}$ & $\begin{array}{l}26.13 \\
\pm 19.38\end{array}$ & $\begin{array}{l}29.41 \\
\pm 21.47\end{array}$ & $\begin{array}{l}27.44 \\
\pm 20.19\end{array}$ & $\begin{array}{l}24.34 \\
\pm 17.73\end{array}$ & $\begin{array}{l}26.03 \\
\pm 19.17\end{array}$ \\
\hline Mean wood debris size ${ }^{*}\left(\mathrm{~m}^{3}\right)$ & $\begin{array}{l}1.07 \\
\pm 1.88\end{array}$ & $\begin{array}{l}0.60 \\
\pm 1.96\end{array}$ & $\begin{array}{l}0.83 \\
\pm 1.64\end{array}$ & $\begin{array}{l}0.74 \\
\pm 1.35\end{array}$ & $\begin{array}{l}0.48 \\
\pm 1.01\end{array}$ & $\begin{array}{l}0.63 \\
\pm 1.22\end{array}$ & $\begin{array}{l}0.60 \\
\pm 1.65\end{array}$ & $\begin{array}{l}0.49 \\
\pm 1.28\end{array}$ & $\begin{array}{l}0.55 \\
\pm 1.49\end{array}$ \\
\hline Total volume (m³) & 329.94 & 250.99 & 580.93 & 351.56 & 251.70 & 603.26 & 407.61 & 234.79 & 642.46 \\
\hline Unit volume (m³/10om) & 18.47 & 20.50 & 20.35 & 19.68 & 23.57 & 21.13 & 22.81 & 21.99 & 22.51 \\
\hline Volume/unit area (m³/ha) & 126.31 & 71.08 & 94.57 & 134.59 & 71.28 & 98.20 & 156.05 & 66.49 & 104.58 \\
\hline
\end{tabular}

Note: For January 2009, September 2009, and September 2010, n = 535 (Qijiawan creek n=274, Gaoshan creek $\mathrm{n}=261$ ), 618 (Qijiawan creek $\mathrm{n}=265$, Gaoshan creek n=353), and 1069 (Qijiawan creek n=484, Gaoshan creek n=585), respectively. * Data are mean \pm S.E. (standard error) 
The wood debris dimensions at Gaoshan Creek were larger than those at Qijiawan Creek for all surveys.

Previous studies (Baillie et al. 2008; Bilby and Ward 1989; Chen et al. 2006; Irouméa et al. 2010; Montgomery et al. 1995) indicated that the channel characteristics play an important role in wood debris storage. The characteristics of wood debris were used to quantify the effects of channel characteristics. A significant correlation between channel width and wood debris was discovered among the independent variables of the channel characteristics category (Figure 4). The abundance and unit volume increased significantly with the channel width in the study area. The wood density decreased with the downstream distance.

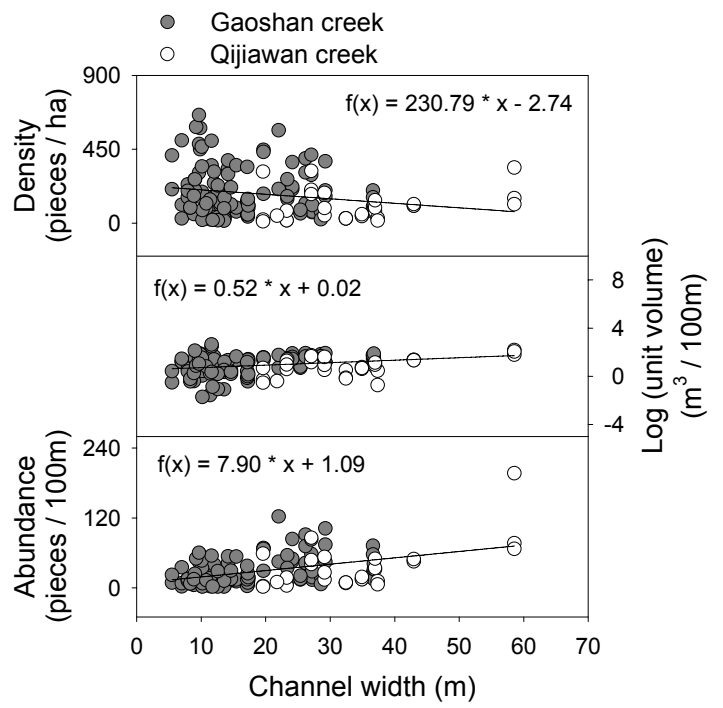

Figure 4 Woody debris characteristics have a significant correlation with channel width. $r$ indicates Person's correlation coefficient and the $p$-values signify degree of significance. Density (pieces/ha): $r$ $=-0.213, p=0.013<0.05$; unit volume $\left(\mathrm{m}^{3} / 100 \mathrm{~m}\right)$ : $r=0.291, p=0.001<0.05$; abundance (pieces/ 100m): $r=0.440, p=0.000<0.05$.

\subsection{Moved wood debris}

Figure 5 shows the variations of the number and dimension of wood debris that entered and exited the study area. A summary of the wood debris characteristics from each field survey is shown in Table 2. The moved wood debris at Gaoshan Creek was more than that at Qijiawan Creek. The wood debris dimensions that entered and exited the study area ranged from 2 to $4 \mathrm{~m}$ in length and from 15 to $25 \mathrm{~cm}$ in diameter. Moreover, the dimensions of wood debris at Gaoshan Creek were larger than those at Qijiawan Creek. This may be due to the wood debris collided with the channel bed, rocks, and each other, causing abrasions and reduced size. In total, 128 ( $55 \mathrm{~m}^{3} ; 1.3 \mathrm{~m}^{3} / 100 \mathrm{~m} ; 8.9$ $\mathrm{m}^{3} / \mathrm{ha}$ ) and 554 (242 m3; $\left.8.5 \mathrm{~m}^{3} / 100 \mathrm{~m} ; 39.4 \mathrm{~m}^{3} / \mathrm{ha}\right)$ new wood debris entered the study area in September 2009 and 2010, respectively. A total of 61 of 552 tagged wood pieces $\left(11 \% ; 36.3 \mathrm{~m}^{3} ; 1.3\right.$ $\left.\mathrm{m}^{3} / 100 \mathrm{~m} ; 5.93 \mathrm{~m}^{3} / \mathrm{ha}\right)$ were transported downstream after Typhoon Morakot. Moreover, $17 \%$ of the tagged wood pieces (107 pieces; $73.8 \mathrm{~m}^{3}$; $2.6 \mathrm{~m}^{3} / 100 \mathrm{~m} ; 12.0 \mathrm{~m}^{3} / \mathrm{ha}$ ) were transported downstream before September 2010. Furthermore, the number of wood debris remaining at Gaoshan Creek was more than that of Qijiawan Creek. A wood jam normally begins with key wood debris that spans across a narrow channel. The trapped wood pieces create a new channel flow (Abbe and Montgomery 2003). The Shei-Pa National Park Headquarters sawed considerable key woods in Gaoshan Creek in July 2010 to prevent trapping large amounts of wood debris along the channel, facilitating the passing of small pieces of wood debris through the channel; thus, the quantity of retrieved wood debris and mobile wood debris increased dramatically.

\section{Discussion}

\subsection{Spatial distribution}

The spatial distribution of wood debris is shown in Figure 6. These results provide qualitative and quantitative observations of the responses of wood debris to channel characteristics at a reach scale. The wood storage is proportional to flow discharge. Large streams typically have a greater capacity to entrain wood debris. Conversely, smaller streams display a lower capacity to move wood debris (Chen et al. 2006; Piégay and Gurnell 1997). The present results are consistent with those of previous studies. However, the present finding further indicates that both abundance and unit volume increase downstream because a discharge increases downstream. Moreover, wood density decreases downstream within a channel network. These trends can be correlated with increasing channel width and decreasing unit stream power. 


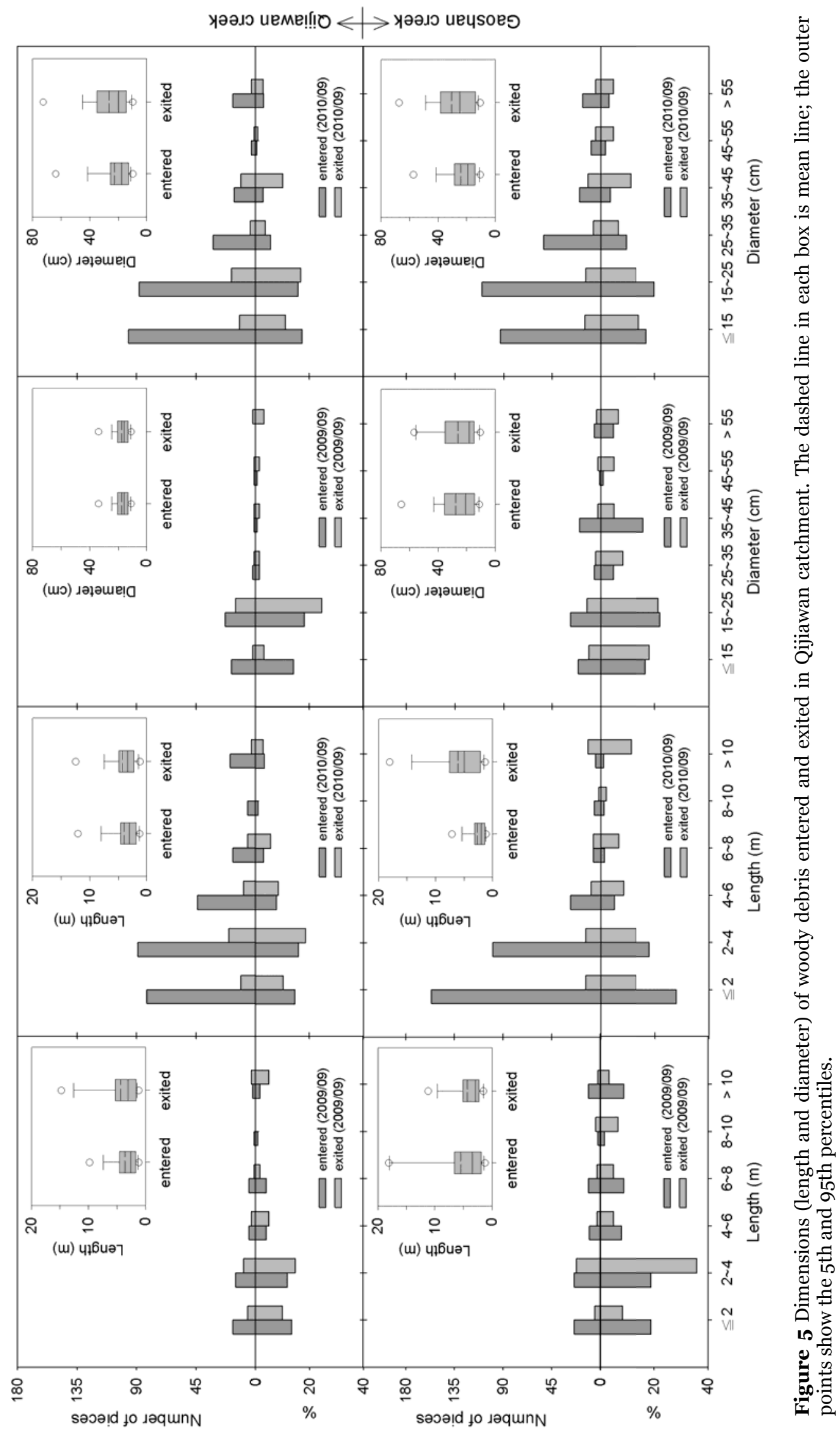


Table 2 Summary characteristics of wood debris moved

\begin{tabular}{|c|c|c|c|c|c|c|}
\hline & \multicolumn{3}{|c|}{ 2009-09 } & \multicolumn{3}{|c|}{ 2010-09 } \\
\hline & $\begin{array}{l}\text { Gaoshan } \\
\text { creek }\end{array}$ & $\begin{array}{l}\text { Qijiawan } \\
\text { creek }\end{array}$ & Total & $\begin{array}{l}\text { Gaoshan } \\
\text { creek }\end{array}$ & Qijiawan creek & Total \\
\hline \multicolumn{7}{|l|}{ Wood debris entered } \\
\hline Total wood pieces & $n=83$ & $n=45$ & $n=128$ & $n=302$ & $n=252$ & $n=554$ \\
\hline Mean length $(\mathrm{m})^{*}$ & $5 \cdot 41 \pm 5 \cdot 33$ & $3.57 \pm 2.66$ & $4.76 \pm 4.65$ & $2.70 \pm 2.05$ & $3.96 \pm 3.23$ & $2.73 \pm 2.73$ \\
\hline Mean diameter $(\mathrm{cm})^{*}$ & $27.16 \pm 21.65$ & $17.82 \pm 7.32$ & $24.88 \pm 18.48$ & $24.20 \pm 17.58$ & $23.35 \pm 17.47$ & $22.78 \pm 17.5^{2}$ \\
\hline Total volume $\left(\mathrm{m}^{3}\right)$ & 46.63 & 8.05 & 54.68 & 126.24 & 115.96 & 242.20 \\
\hline Unit volume (m³/100m) & 2.61 & 0.75 & 1.29 & 7.07 & 10.86 & 8.48 \\
\hline Volume/unit area (ha) & 17.85 & 2.28 & 8.90 & 48.33 & 32.84 & 39.43 \\
\hline \multicolumn{7}{|l|}{ Wood debris exited } \\
\hline Total wood pieces & $n=39$ & $n=22$ & $n=61$ & $n=58$ & $n=49$ & $n=107$ \\
\hline Mean length* $(\mathrm{m})$ & $4.27 \pm 2.90$ & $4.35 \pm 3.90$ & $4.30 \pm 3.27$ & $6.06 \pm 5.12$ & $4.15 \pm 3.05$ & $5.18 \pm 4.38$ \\
\hline Mean diameter* $(\mathrm{cm})$ & $26.02 \pm 15.79$ & $26.99 \pm 21.64$ & $26.37 \pm 17.95$ & $30.47 \pm 24.29$ & $26.56 \pm 19.37$ & $28.68 \pm 22.16$ \\
\hline Total volume (m³) & 23.02 & 13.25 & 36.28 & 48.90 & 24.94 & 73.84 \\
\hline Unit volume (m³/100m) & 1.29 & 1.24 & 1.27 & 2.74 & 2.34 & 2.59 \\
\hline Volume/unit area (ha) & 8.81 & 3.75 & 5.91 & 18.72 & 7.06 & 12.02 \\
\hline
\end{tabular}

Note: Wood debris recruited means the new wood debris was found in the study reach on September, 2009 and 2010; wood debris mobile means the tagged wood missing in the study reach on September, 2009 and $2010 .{ }^{*}$ Data are mean \pm S.E. (standard error).

In the first-order stream (Gaoshan Creek), over $45 \%$ of the wood debris was stored within the channel or along the bank (Table 3). A portion of the wood debris (approximately 30\%) was distributed on or adjacent to the floodplain. The remainder often remained on the channel floor, across, or partly across the channel, blocking the original streamflow and assisting it in creating a new streamflow or new channel morphology such as wood steps. In the second-order stream (Qijiawan Creek), most of the wood debris (over $75 \%)$ was distributed on the adjacent floodplain, and the remainder was distributed on the bank edge.

\subsection{Accumulative distribution}

Figure 7 shows the temporal and spatial correlation of the wood debris with its channel width, vertical distance, and cumulative percentage. The rates of the cumulative percentage at Qijiawan Creek are higher than those at Gaoshan Creek in all our field surveys. Approximately 50\%, 65\%, and $60 \%$ of the wood debris at Qijiawan Creek was retrieved in January 2009, September 2009, and September 2010, respectively. The cumulative percentage increase is considerable (50\% to $65 \%$ ) but decreases significantly in the later stages $(65 \%$ to $60 \%$ ). The increase can be attributed to the large amounts of wood debris that washed into the channel and was transported downstream during the floods induced by Typhoon Morakot. The decrease may be due to the operational management of wood debris by Shei-Pa National

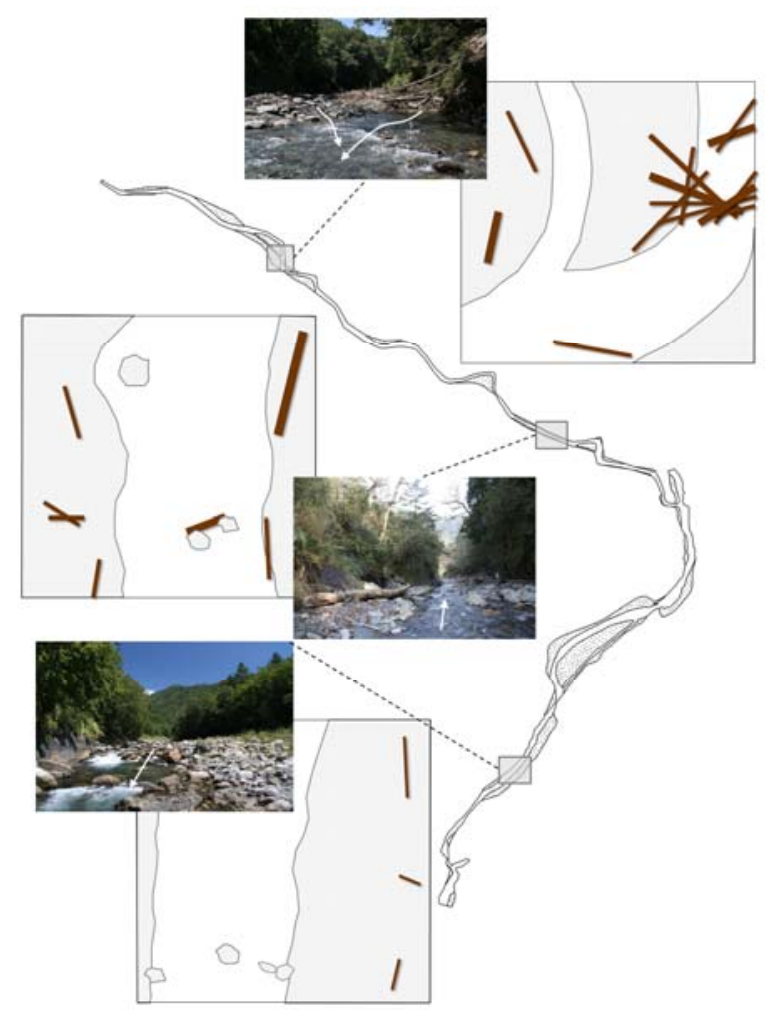

Figure 6 A sketch map of woody debris spatial distribution along the study reach (not to scale). 
Table 3 Spatial distribution of wood debris locations and orientations

\begin{tabular}{|l|c|c|c|c|c|c|c|c|c|c|}
\hline & \multicolumn{3}{|c|}{ 2009-01 } & \multicolumn{4}{c|}{ 2009-09 } \\
& $\begin{array}{l}\text { Gaoshan } \\
\text { creek }\end{array}$ & $\begin{array}{l}\text { Qijiawan } \\
\text { creek }\end{array}$ & Total & $\begin{array}{l}\text { Gaoshan } \\
\text { creek }\end{array}$ & $\begin{array}{l}\text { Qijiawan } \\
\text { creek }\end{array}$ & Total & $\begin{array}{l}\text { Gaoshan } \\
\text { creek }\end{array}$ & $\begin{array}{l}\text { Qijiawan } \\
\text { creek }\end{array}$ & Total \\
\hline Locations & $n=261$ & $n=291$ & $n=552$ & $n=354$ & $n=265$ & $n=619$ & $n=584$ & $n=484$ & $n=1,068$ \\
\hline Adjacent floodplain & 12 & 83 & 50 & 51 & 75 & 62 & 28 & 77 & 50 \\
\hline Bank edge & 57 & 13 & 34 & 35 & 24 & 30 & 44 & 22 & 34 \\
\hline Across channel & 2 & 1 & 1 & 8 & 0 & 5 & 1 & 0 & 1 \\
\hline Partly across channel & 0 & 0 & 0 & 2 & 0 & 1 & 6 & 0 & 3 \\
\hline Channel floor & 29 & 3 & 15 & 4 & 0 & 2 & 21 & 1 & 12 \\
\hline Orientations & $n=256$ & $n=289$ & $n=545$ & $n=384$ & $n=261$ & $n=609$ & $n=587$ & $n=488$ & $n=1,075$ \\
\hline Parallel & 45 & 36 & 40 & 41 & 44 & 42 & 36 & 35 & 36 \\
\hline Perpendicular & 34 & 32 & 33 & 34 & 26 & 31 & 29 & 32 & 31 \\
\hline Oblique & 21 & 32 & 27 & 25 & 30 & 27 & 34 & 32 & 33 \\
\hline
\end{tabular}

Note: For 2009-01, 2009-09, and 2010-09. All data are presented as percentages.

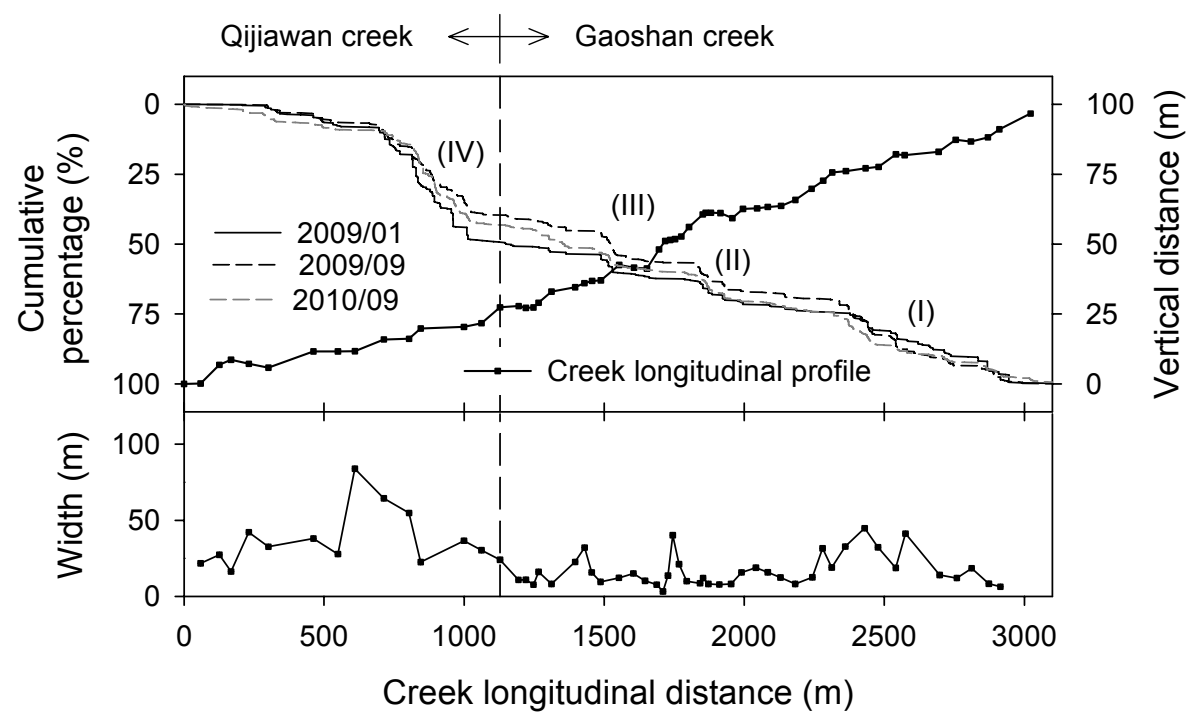

Figure 7 Cumulative accumulation (upstream to downstream) of all woody debris during January 2009 (black line), September 2009 (dashed line), and September 2010 (dashed dotted line) in the studied reach, with stream longitudinal profile (square-black line); the vertical dashed lines indicate stream confluences. (II) is at the \#1 and \#2; (III) is at \#3, and (IV) is at \#6 in 8 .

Park Headquarters. The four segments (Segments I to IV) in Figure 7 show the data regarding the rapidly accumulating wood debris. Figure 8 shows the corresponding photos to the sites of the segments. Wood debris has a tendency to spread and store in wide or braided channel sections because of a relatively low stream transport ability (Marcus et al. 2002). The increased channel width causes the accumulation of wood debris in Segment IV (\#6 in Figure 8). Landslides along the stream introduce a significant amount of wood debris into the stream channel in Segment II (\#1 in Figure 8). Riparian vegetation performs a key role in obstructing mobile wood debris in Segment III (\#3 in Figure 8). The foregoing results indicate that channel width, landslides, and riparian vegetation enhance the accumulative distribution of wood debris in the study area.

\subsection{Movement of wood debris}

The movement of wood debris in streams is strongly related to its length; most pieces that move are shorter than the bankfull width (Lienkaemper and Swanson 1987; Warren et al. 2009). Chen et al. (2006) used the stability index $(v)$, defined as the ration of wood debris length and channel width $\left(l_{w} / W\right)$, to describe the stability of 


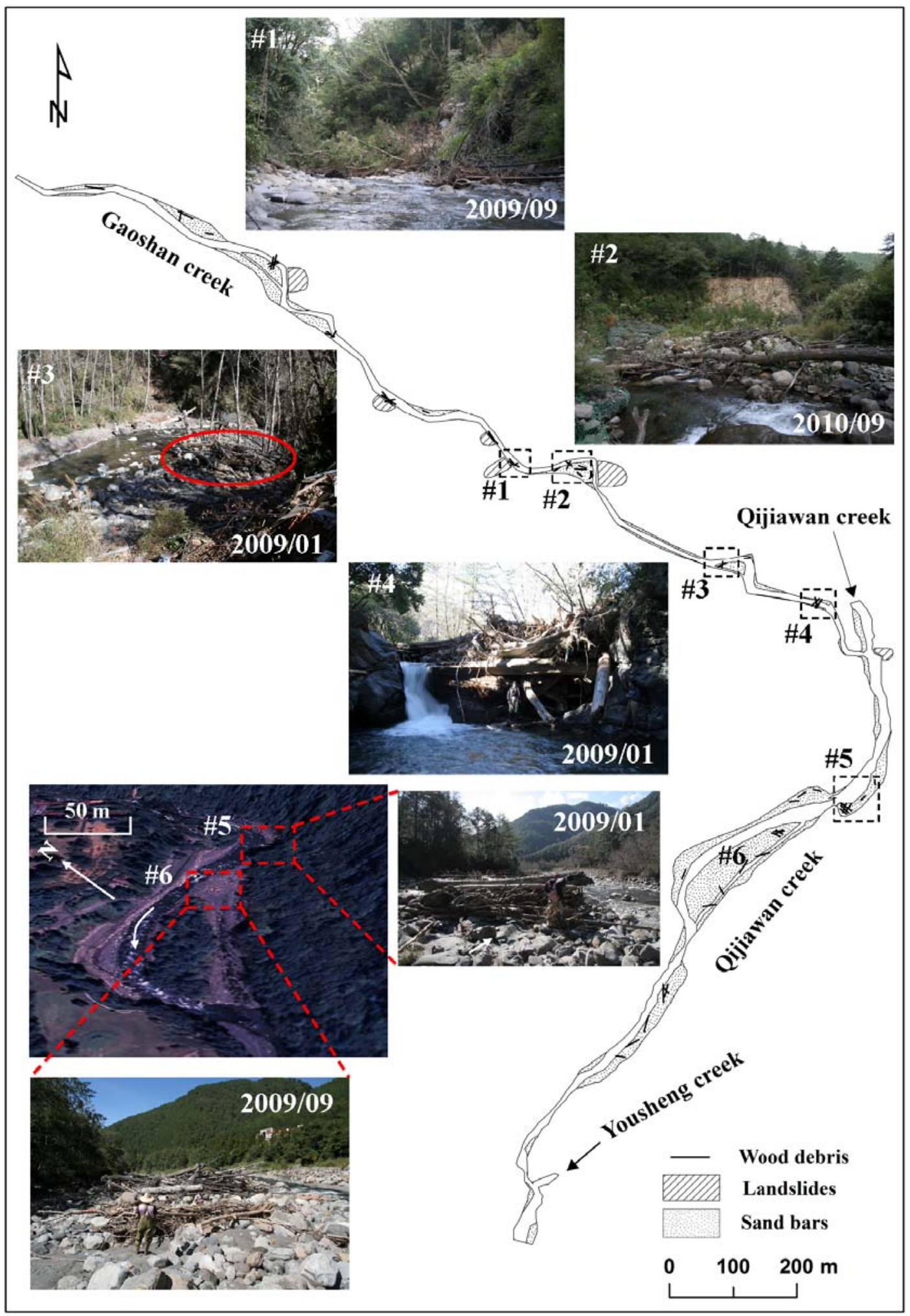

Figure 8 Map of woody debris distribution in the studied reach. The woody debris distribution is schematic and not to scale. \#1 and \#2 show the riparian landslide and large wood debris deposited in front of the sandbar; \# 3 shows wood debris was obstructed by riparian vegetation; \#5 describes a topographical notch; \#6 shows amounts of woody debris spread along the channel with channel width increasing. 
wood debris in relation to stream size. The results showed that the stability indices were $0.22,0.20$, and 0.17 for successive surveys in this study; therefore, a small $v$ indicates a high instability. Braudrick and Grant (2000) demonstrated that the stability of wood debris increases if it is parallel to the stream flow orientation in the channel. In the study area, more than $50 \%$ of the wood debris is perpendicular and oblique to the steamflow orientations in the study area (Table 3). Both the stability index value and the orientation of wood debris suggest that the wood debris in the study area is easily transported downstream during flood events. From January to September of 2009, $55 \mathrm{~m}^{3}$ $\left(1.76 \mathrm{~m}^{3} / 100 \mathrm{~m}, 127\right.$ pieces) of wood debris entered the study area, and $36 \mathrm{~m}^{3}\left(1.17 \mathrm{~m}^{3} / 100 \mathrm{~m}, 61\right.$ pieces $)$ exited the stream. From 2009 to $2010,242 \mathrm{~m}^{3}$ $\left(7.81 \mathrm{~m}^{3} / 100 \mathrm{~m}, 560\right.$ pieces) of wood pieces entered and $74 \mathrm{~m}^{3}\left(2.38 \mathrm{~m}^{3} / 100 \mathrm{~m}, 107\right.$ pieces $)$ exited the study area. In our study area, $11 \%$ and $17 \%$ of the wood pieces were transported downstream during the flood events in 2009 and 2010, respectively. Irouméa et al. (2010) showed that $12 \%$ of the wood debris in the western coastal mountain of Valdivia, Chile, was transported downstream. Approximately $26 \%$ of the wood debris moved during floods in the 4-year survey at Adirondack Mountain, NY, USA (Warren and Kraft 2008). Our results indicate that the potential for wood debris movement in the high gradient catchment is stronger than that of other regions.

The critical depth for floatation can be calculated using the following equation (Braudrick et al. 1997):

$$
d_{c}=r+r^{2}\left[\frac{\pi\left(\rho_{l} / \rho_{w}-1 / 2\right)-\sin ^{-1}\left(d_{c}-r / r\right)}{\sqrt{2 d_{c} r-d_{c}^{2}}}\right]
$$

where $r$ is the wood radius (m) and $d_{c}$ is the critical depth for floatation (m). The Manning formula with $d_{c}$ was used to calculate the threshold for wood movement. Three flood events, Typhoon Jangmi, Typhoon Morakot, and 0911 flood due to heavy rainfall, were selected to evaluate the entrainment of wood debris with given transport conditions. The discharges of Gaoshan Creek and Qijiawan Creek were estimated using the ratios of the specific catchment areas to catchment areas obtained from the Qijiawan Creek discharge station. The discharges for wood threshold were less than the discharges of the flood events, as shown in Figure 9 (a). The threshold mean unit discharge is $0.34 \mathrm{~m}^{2} / \mathrm{s}$ (ranging from 0.05 to 2.3 $\mathrm{m}^{2} / \mathrm{s}$ ) in the study region. These results indicate that regular flood events are significant factors that facilitate the entrainment and transport of wood debris in the study area.
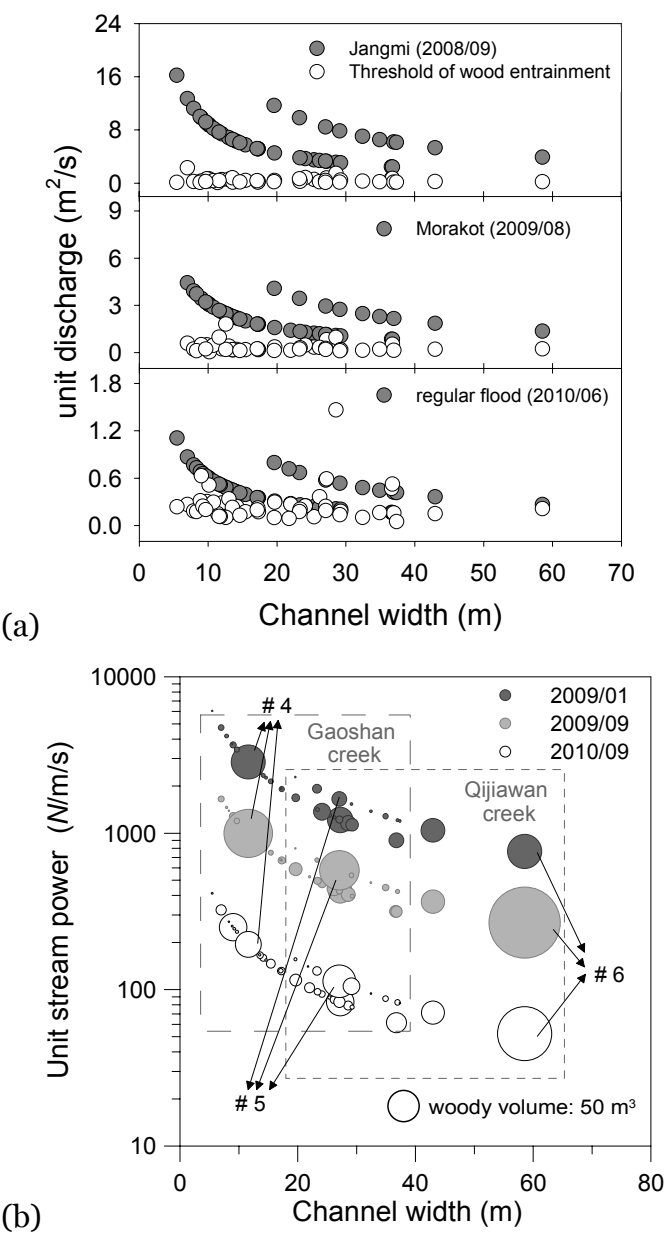

Figure 9 Correlation between threshold unit discharges of wood entrainment and migration of wood debris during the Typhoon Jangmi and Morakot and regular flood event. (a) shows the wood entrainment threshold during the flood events; (b) shows the relationship between relative unit stream power $(\mathrm{N} / \mathrm{m} / \mathrm{s})$ and variation of wood debris migration.

Moreover, unit stream power was used to represent the ability of streams to transport wood debris in the study area. Unit stream power was calculated using $\omega=\gamma q S$, where $\omega$ is the unit stream power $(\mathrm{N} / \mathrm{m} / \mathrm{s}), \gamma$ is the specific weight of water $\left(9,800 \mathrm{~N} / \mathrm{m}^{3}\right), q$ is the unit peak discharge of the flood event $\left(\mathrm{m}^{2} / \mathrm{s}\right)$, and $S$ is the mean channel gradient $(\mathrm{m} / \mathrm{m})$. Figure 9 (b) shows the unit stream power with the channel width for Gaoshan Creek 


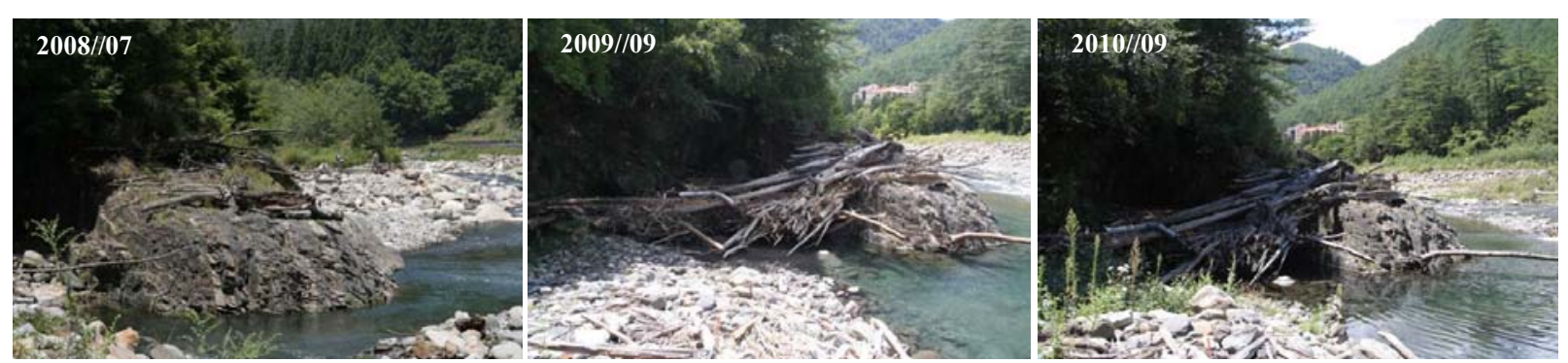

Figure 10 the migration of wood debris before and after the flood events at special geological structure in the study stream.

and Qijiawan Creek. The volumes of the moved wood debris are presented in size the data cycle to obtain direct comparisons. The volumes of wood debris stored along Gaoshan Creek were larger than those along Qijiawan Creek, which can be attributed to the tendency of wood debris to store along wide channels with low stream power (Baillie et al. 2008; Chen et al. 2006; Seo et al. 2010; Wyżga and Zawiejska 2005).

Moreover, the results show that the wood debris has a tendency to store at locations with certain channel characteristics. Sites with a wood debris dam development, topographical notch, and special geological structure had a relatively large amount of wood debris.

The two-braided wide channel in Qijiawan creek caused the velocities to decrease during the flood. Wood debris movement was suspended, causing gradual spread on the floodplain and lower transport ability (\#6 in Figure 9 (b)). The volume of wood debris varied from $22 \mathrm{~m}^{3}$ to $64 \mathrm{~m}^{3}$ during the survey periods. Moreover, wood debris dam development is a key to reducing the potential migration of wood debris (Warren and Kraft 2008). It caused the volume of migratory wood debris to vary from $55 \mathrm{~m}^{3}, 79 \mathrm{~m}^{3}$, to $41 \mathrm{~m}^{3}$ during the surveys (\#4 in Figure 9 (b)). The topographical notch creates a slow flow zone. The wood debris is influenced by the slow flow and deposits in this zone when the wood debris is transported through this section. The survey shows that a significant variation in the volume of wood debris occurred because of the topographical notch. The volume varied sequentially from $55 \mathrm{~m}^{3}, 117 \mathrm{~m}^{3}$, to $88 \mathrm{~m}^{3}$ (\#5 in Figure 9 (b)). Furthermore, a special geological structure may recruit wood debris and increase its volume in a stream. Figure 10 shows that a large rock-accumulated wood debris during the flood events.

\section{Conclusions}

This study contributes to the quantification of wood debris characteristics, and shows the transportation of wood debris before and after flood events in a steep mountain stream. The study area is downstream of Gaoshan Creek and Qijiawan Creek, located at the Qijiawan catchment in Shei-Pa National Park of Central Taiwan. Field surveys were performed to identify the wood debris in the study area and the wood debris dimensions were recorded. As a result, the channel width, landslides, and riparian vegetation have a significant correlation with the cumulative distribution of wood debris in the study area. The channel width has an important role in wood debris storage. A correlation between channel width and wood debris variables is discovered. The ability of wood debris movement transportation is powerful in the steep stream system because of a relatively high unit stream power. Wood debris has a tendency to store along wide channels with low stream power. Moreover, the sites with development of wood debris dam, topographical notches, and unique geological structures have a relatively large amount of wood debris. The stability index value and the orientation of wood debris suggest that wood debris in the study area is easily transported downstream during flood events. Moreover, the critical depth for threshold of wood debris movement shows that the regular flood events are a significant factor in facilitating wood debris movement. It is demonstrated that the wood debris migration in the study area is greater than in other regions. These findings assist in the understanding of the effects of channel characteristics on the distributions of wood debris in steep stream systems. 


\section{Acknowledgements}

The authors would like to thank the Taiwan Science Council for financially supporting this

\section{References}

Abbe TB, Montgomery DR (2003) Patterns and processes of wood debris accumulation in the Queets river basin, Washington. Geomorphology 51(1-3): 81-107. Doi: 10.1016/ s0169-555x(02)00326-4.

Andrus CW, Long BA, Froehlich HA (1988) Woody debris and its contribution to pool formation in a coastal stream 50 years after logging. Canadian Journal of Fisheries and Aquatic Sciences, 45(12): 2080-2086. Doi: 10.1139/f88-242.

Baillie BR, Garrett LG, Evanson AW (2008) Spatial distribution and influence of large woody debris in an old-growth forest river system, New Zealand. Forest Ecology and Management 256(1-2): 20-27. Doi: 10.1016/j.foreco.2008.01.051.

Bilby RE, Ward JW (1989) Changes in characteristics and function of woody debris with increasing size of streams in Western Washington. Transactions of the American Fisheries Society 118(4): 368-378. Doi: 10.1577/1548-8659(1989)118 $<0368$ :cicafo> 2.3.co;2.

Bilby RE (1981) Role of organic debris dams in regulating the export of dissolved and particulate matter from a forested watershed. Ecology 62(5):1234-1243

Braudrick CA, Grant GE, Ishikawa Y, et al. (1997) Dynamics of Wood Transport in Streams: A Flume Experiment. Earth Surface Processes and Landforms 22(7): 669-683. Doi: 10.1002/(sici)1096-9837(199707)22:7<669::aidesp740>3.0.c o;2-1.

Braudrick CA, Grant GE (2000) When do logs move in rivers? Water Resources Research 36(2): 571-583. Doi: 10.1029/ 1999wr900290.

Chen X, Wei X, Scherer R, et al. (2006) A watershed scale assessment of in-stream large woody debris patterns in the southern interior of British Columbia. Forest Ecology and Management 229(1-3): 50-62. Doi:10.1016/j.foreco.2006.03. o10.

Gippel CJ (1995) Environmental hydraulics of large woody debris in streams and rivers. Journal of Environmental Engineering 121: 388-395.

Gurnell AM, Piégay H, Swanson FJ, et al. (2002) Large wood and fluvial processes. Freshwater Biology 47(4): 601-619. Doi: 10.1046/j.1365-2427.2002.00916.x.

Harmon ME, Franklin JF, Swanson FJ, et al. (1986) Ecology of coarse woody debris in temperate ecosystems. In: MacFadyen A, Ford ED (eds.) Advances in Ecological Research, vol 15 Academic Press, Inc., Orlando, FL. pp 133-302.

Harmon ME, Sexton J (1996) Guidelines for Measurements of Woody Detritus in Forest Ecosystems. Publication No. 20. US LTER Network Office. University of Washington. Seattle. WA. USA.

Hilton RG, Galy A, Hovius N, et al. (2008) Tropical-cyclonedriven erosion of the terrestrial biosphere from mountains. Nature Geoscience 1(11): 759-762. Doi: 10.1038/ngeo333.

Irouméa A, Andrea A, Comiti F, et al. (2010) Large wood abundance, distribution and mobilization in a third order Coastal mountain range river system, southern Chile. Forest Ecology and Management 260(4): 480-490. Doi: 10.1016/ j.foreco.2010.05.004.

Keller EA, Swanson FJ (1979) Effects of large organic material on channel form and fluvial processes. Earth Surface Processes 4(4): 361-380. Doi: 10.1002/esp.3290040406. research under Contract No. NSC 96-2625-Zoo5o01-MY3.
Latterell JJ, Naiman RJ (2007) Sources and dymamics of large logs in a temperate floodplain river. Ecological Applications 17(4): 1127-1141. Doi: 10.1890/06-0963.

Lienkaemper GW, Swanson FJ (1987) Dynamics of large woody debris in streams in old-growth Douglas-fir forests. Canadian Journal of Forest Research 17(2): 150-156. Doi: 10.1139/x87027

Lu SY, Hwang LS (2006) Disscusion on relative issues of driftwood in flood. Forestry Research News letter 13: 21-24. (In Chinese)

Manners RB, Doyle MW (2008) A mechanistic model of woody debris jam evolution and its application to wood-based restoration and management. River Research and Applications 24(8): 1104-1123. Doi: 10.1002/rra.1108.

Marcus WA, Marston RA, Colvard JrCR, et al. (2002) Mapping the spatial and temporal distributions of woody debris in streams of the Greater Yellowstone Ecosystem, USA. Geomorphology 44(3-4): 323-335. Doi: 10.1016/So169-555X (01)00181-7.

Martin DJ, Benda LE (2001) Patterns of instream wood recruitment and transport at the watershed scale. Transactions of the American Fisheries Society 130(5): 940958. Doi: 10.1577/1548-8659(2001)130<0940:poiwra>2.0.co;

Montgomery DR, Buffington JM, Smith RD, et al. (1995) Pool spacing in forest channels. Water Resources Research 31(4): 1097-1105. Doi: 10.1029/94wro3285.

Nakamura F, Swanson FJ (1993) Effects of coarse woody debris on morphology and sediment storage of a mountain stream system in western Oregon. Earth Surface Processes and Landforms 18(1): 43-61. Doi: 10.1002/esp.3290180104.

Piégay H, Gurnell AM (1997) Large woody debris and river geomorphological pattern: examples from S.E. France and S. England. Geomorphology 19(1-2): 99-116. Doi: 10.1016/So169 -555X(96)00045-1.

Seo J, Nakamura F, Chun K (2010) Dynamics of large wood at the watershed scale: a perspective on current research limits and future directions. Landscape and Ecological Engineering 6(2): 271-287. Doi:10.1007/s11355-010-0106-3.

Warren DR, Kraft CE, Keeton WS, et al. (2009) Dynamics of wood recruitment in streams of the northeastern US. Forest Ecology and Management 258(5): 804-813. Doi:10.1016/ j.foreco.2009.05.020.

Warren DR, Kraft CE (2008) Dynamics of large wood in an eastern U.S. mountain stream. Forest Ecology and Management 256(4): 808-814. Doi: 10.1016/j.foreco.2008. 05.038.

West AJ, Lin CW, Lin TC, et al. (2011) Mobilization and transport of coarse woody debris to the oceans triggered by an extreme tropical storm. Limnology and oceanography 56(1): 77-85. Doi: 10.4319/lo.2011.56.1.0077.

Wohl E, Ogden FL, Goode J (2009) Episodic wood loading in a mountainous neotropical watershed. Geomorphology 111(3-4): 149-159. Doi: 10.1016/j.geomorph.2009.04.013.

Wyżga B, Zawiejska J (2005) Wood storage in a wide mountain river: case study of the Czarny Dunajec, Polish Carpathians. Earth Surface Processes and Landforms 30(12): 1475-1494. Doi: 10.1002/esp.1204. 